\title{
Improving the Prediction of Processing Pea Maturity Based on the Growing- degree Day Approach
}

\author{
Gaétan Bourgeois ${ }^{1}$, Sylvie Jenni, Hélène Laurence, and \\ Nicolas Tremblay \\ Agriculture and Agri-Food Canada, Horticultural Research and Development \\ Centre, Saint-Jean-sur-Richelieu (Que.), J3B 3E6, Canada
}

Additional index words. heat units, Pisum sativum, phenology, base temperature

\begin{abstract}
The heat-unit system, involving the sum of daily mean temperatures above a given base temperature, is used with processing pea (Pisum sativum $\mathrm{L}$.) to predict relative maturity during the growing season and to schedule planting dates based on average temperature data. The Quebec pea processing industry uses a base temperature of $5^{\circ} \mathrm{C}$ to compute growing-degree days (GDD) between sowing and maturity. This study was initiated to verify if the current model, which uses a base temperature of $5^{\circ} \mathrm{C}$, can be improved to predict maturity in Quebec. Four pea cultivars, 'Bolero', 'Rally', 'Flair', and 'Kriter', were grown between 1985 and 1997 on an experimental farm in Quebec. For all cultivars, when using a limited number of years, a base temperature between 0.0 and 0.8 ${ }^{\circ} \mathrm{C}$ reduced the coefficient of variation (Cv) as compared with $5.0{ }^{\circ} \mathrm{C}$, indicating that the base temperature used commercially is probably not the most appropriate for Quebec climatic conditions. The division of the developmental period into different stages (sowing until emergence, emergence until flowering, and flowering until maturity) was also investigated for some years. Use of base temperatures specific for each crop phase did not improve the prediction of maturity when compared with the use of an overall base temperature. All years for a given cultivar were then used to determine the base temperature with the lowest $\mathrm{cv}$ for predicting the time from sowing to maturity. A base temperature from 0 to $5^{\circ} \mathrm{C}$ was generally adequate for all cultivars, and a common base temperature of $3.0^{\circ} \mathrm{C}$ was selected for all cultivars. For the years and cultivars used in this study, the computation of GDD with a base temperature of $3^{\circ} \mathrm{C}$ gave an overall prediction of maturity of 2.0, 2.4, 2.2, and 2.5 days based on the average of the absolute values of the differences for the cultivars Bolero, Rally, Flair, and Kriter, respectively.
\end{abstract}

The heat-unit system, involving the sum of daily mean temperatures above a given base temperature, is used with processing pea to predict relative maturity during the growing season and to schedule planting dates based on average temperature data. A base temperature of $4.4{ }^{\circ} \mathrm{C}$ was often reported to be the most satisfactory for green peas (Borchers, 1981; Boswell, 1927; Katz, 1952; Rubatzky and Yamaguchi, 1997; Swiader et al., 1992). However, the base temperature varies depending on the heat requirement of pea types. A base temperature of $6.6^{\circ} \mathrm{C}$ was selected for southern pea (Hoover, 1955), while $0{ }^{\circ} \mathrm{C}$ was selected for cold-tolerant winter pea (Ney and Turc, 1993).

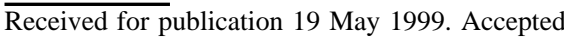
for publication 18 Nov. 1999. Agr. and Agri-Food Can., Saint-Jean-sur-Richelieu (Que.), Contribution no. 335/99.11.01R. We thank Lucette LaFlamme and Geneviève Roy for their technical assistance, the Quebec Food Processors Assn., the Fédération québécoise des producteurs de fruits et légumes transformés and the Centre de technologies en agroenvironnement for their financial contribution, as well as the field workers at the L'Acadie experimental farm for their help. The cost of publishing this paper was defrayed in part by the payment of page charges. Under postal regulations, this paper therefore must be hereby marked advertisement solely to indicate this fact.

${ }^{1}$ E-mail address: bourgeoisg@em.agr.ca
}

1955; Lorenz and Maynard, 1988). After germination, the optimal growth temperature ranges between 10 and $19^{\circ} \mathrm{C}$ (Chaux and Foury, 1994; Lorenz and Maynard, 1988; Rubatzky and Yamaguchi, 1997; Swiader et al., 1992). Depending on varietal and environmental conditions, a pea crop takes $56-75 \mathrm{~d}$ to reach maturity after planting (Lorenz and Maynard, 1988). Minimum temperature for growth is $\approx 4$ to $7^{\circ} \mathrm{C}$, with lower temperature causing primordia leaf destruction at the flower initiation stage and serious damage to flower buds after flowering (Chaux and Foury, 1994; Lorenz and Maynard, 1988; Swiader et al., 1992). A daily mean of 20 ${ }^{\circ} \mathrm{C}$ was found to be near the critical point, with higher temperatures having adverse effects (Boswell, 1929; Ney et al., 1993). The period of 5-11 d after full bloom was reported as particularly sensitive to high temperature, with $27^{\circ} \mathrm{C}$ being a critical level above which yields were reduced (Karr et al., 1959; Lambert and Linck, 1958; Nonnecke et al., 1971).

The Quebec pea processing industry uses a base temperature of $5^{\circ} \mathrm{C}$ to compute growing-degree days (GDD) between sowing and maturity. The objective of this study was to verify if the current model, which uses a base temperature of $5{ }^{\circ} \mathrm{C}$, can be improved to predict pea maturity in Quebec. Furthermore, the division of the developmental period into different stages (sowing until emergence, emergence until flowering, flowering until maturity) was also investigated.

\section{Materials and Methods}

Field layout. Four pea cultivars were grown between 1985 and 1997 on loamy or clayey soils at the experimental farm of the Horticultural Research and Development Centre of Agr. and Agri-Food Can. located at L'Acadie, $20 \mathrm{~km}$ southeast of Montreal, Que. (lat. $45^{\circ} 19^{\prime} \mathrm{N}$, long. $\left.73^{\circ} 21^{\prime} \mathrm{W}\right)$. Since 1985 , continuous trials have provided information on varieties. The cultivars included 'Bolero' (large sieve size), 'Rally' and 'Flair' (medium sieve size), and 'Kriter' (small sieve size), supplied by Asgrow Seed Co. (London, Ont., Can.) (Table 1).

Sowing occurred between the second week of May and the first week of June depending on the year (Table 2). Peas were sown using a John Deere 9350 seeder (Moline, Ill.) at a rate of $25-30$ seeds per meter and a depth of $\approx 2.5$ $\mathrm{cm}$ (3.5-4.5 cm under dry conditions). Each plot measured $15 \times 1.68 \mathrm{~m}$ and included 12 rows spaced at $15 \mathrm{~cm}$. The field layout was arranged in a randomized complete-block design with four blocks. Nitrogen was applied at a rate of $15-30 \mathrm{~kg} \cdot \mathrm{ha}^{-1}$ depending on year and phosphorus and potassium according to

\begin{tabular}{lccccccc}
\hline \hline Cultivar & $\begin{array}{c}\text { Node no. } \\
\text { first bloom }\end{array}$ & $\begin{array}{c}\text { No. days } \\
\text { for processing }\end{array}$ & $\begin{array}{c}\text { Plant ht } \\
(\mathrm{cm})\end{array}$ & $\begin{array}{c}\text { Pod length } \\
(\mathrm{cm})\end{array}$ & $\begin{array}{c}\text { Pod width } \\
(\mathrm{cm})\end{array}$ & $\begin{array}{c}\text { No. seeds/ } \\
\text { pod }\end{array}$ & $\begin{array}{c}\text { Seed wt } \\
(\mathrm{g} / 100 \text { seeds })\end{array}$ \\
\hline Bolero & 15 & 73 & 67 & 8 & 13 & 8 & 18 \\
Rally & 11 & 70 & 35 & 6 & 11 & 8 & 17 \\
Flair & 11 & 69 & 45 & 7 & 11 & 8 & 15 \\
Kriter & 11 & 69 & 40 & 6 & 12 & 8 & 14 \\
\hline
\end{tabular}

${ }^{\mathrm{z}}$ Source: Plant variety protection office (Beltsville, Md.).

Heat-unit systems often predict the devel-
pmental time from seeding to crop maturity. However, the idea of using checkpoints during e gernination. Ney and Turc (1993) used three the heat-unit system changes with developmental stages of cold-tolerant winter peas: soil temperature of $1^{\circ} \mathrm{C}$ for seedling emergence and The optimal temperature for a pea crop will vary with its growth stage. Best germination occurs between 25 and $30^{\circ} \mathrm{C}$, with a minimum at $10{ }^{\circ} \mathrm{C}$ and a maximum at $35^{\circ} \mathrm{C}$ (Hoover,

Table 1. Information on processing pea cultivars. ${ }^{\mathrm{z}}$

.

.


soil tests. Weed control was performed using a preemergence herbicide and then manually when required. Irrigation was applied immediately after seeding, when needed, and thereafter supplemental irrigation was applied only during dry periods.

Plant emergence was defined as the time when an average of $80 \%$ of the seeds of all cultivars were at the cotyledon stage, and flowering time when $10 \%$ of the plants showed at least one flower. This latter stage was used to characterize the beginning of flowering.

In the center of each plot, $10 \mathrm{~m}$ of 12 rows were harvested by hand. Maturity was determined according to tenderness using a tenderometer (Food Machinery Corp., Hoopeston, Ill.) from 1985 to 1992, and an electronic tenderometer (Food Tech. Corp., Rockland, Md.) from 1993 to 1997. Tenderness criteria varied according to pea size: 100 for the small sieve size, 105 for the medium, and 110 for the large. Daily minimum (Tmin) and maximum (Tmax) temperatures at a height of $1.2 \mathrm{~m}$ were recorded from a weather station located on the experimental farm at 400-500 $\mathrm{m}$ from the plots. Average temperatures for each growing period are given in Fig. 1.

Analysis procedure. The cumulative GDD required to reach emergence, flowering, and

Table 2. Sowing, emergence (Emerg.), flowering (Flower.), and maturity dates for four pea cultivars from 1985 to 1997 at L'Acadie, Que., Canada.

\begin{tabular}{|c|c|c|c|c|c|c|c|c|c|c|}
\hline & & & \multicolumn{8}{|c|}{ Cultivar } \\
\hline \multicolumn{3}{|c|}{ All cultivars } & \multicolumn{2}{|c|}{ Bolero } & \multicolumn{2}{|c|}{ Rally } & \multicolumn{2}{|c|}{ Flair } & \multicolumn{2}{|c|}{ Kriter } \\
\hline$\overline{1985}$ & 14 May & --- & --- & --- & 25 June & 19 July & --- & --- & 25 June & 15 July \\
\hline 1988 & 1 June & --- & --- & --- & 10 July & 25 July & --- & --- & 8 July & 24 July \\
\hline 1989 & 18 May & --- & 26 June & 15 July & 23 June & 11 July & 22 June & 11 July & 23 June & 8 July \\
\hline 1990 & 9 May & --- & 27 June & 19 July & 21 June & 14 July & 21 June & 14 July & 21 June & 13 July \\
\hline 1991 & 13 May & --- & 26 June & 10 July & 19 June & 7 July & --- & --- & 18 June & 4 July \\
\hline 1994 & 21 May & 30 May & 2 July & 18 July & 26 June & 13 July & 27 June & 13 July & 26 June & 11 July \\
\hline 1995 & 10 May & 20 May & 22 June & 8 July & 19 June & 4 July & 18 June & 3 July & 18 June & 1 July \\
\hline 1996 & 9 May & 20 May & 23 June & 16 July & 16 June & 11 July & 26 June & 14 July & --- & --- \\
\hline 1997 & 22 May & 2 June & 1 July & 18 July & 26 June & 16 July & --- & --- & --- & --- \\
\hline
\end{tabular}

Table 3. Base temperatures and corresponding coefficients of variation (cv) values for estimating developmental time (growing-degree days) from sowing to maturity of four pea cultivars using four approaches integrating sowing, emergence, flowering, and maturity times.

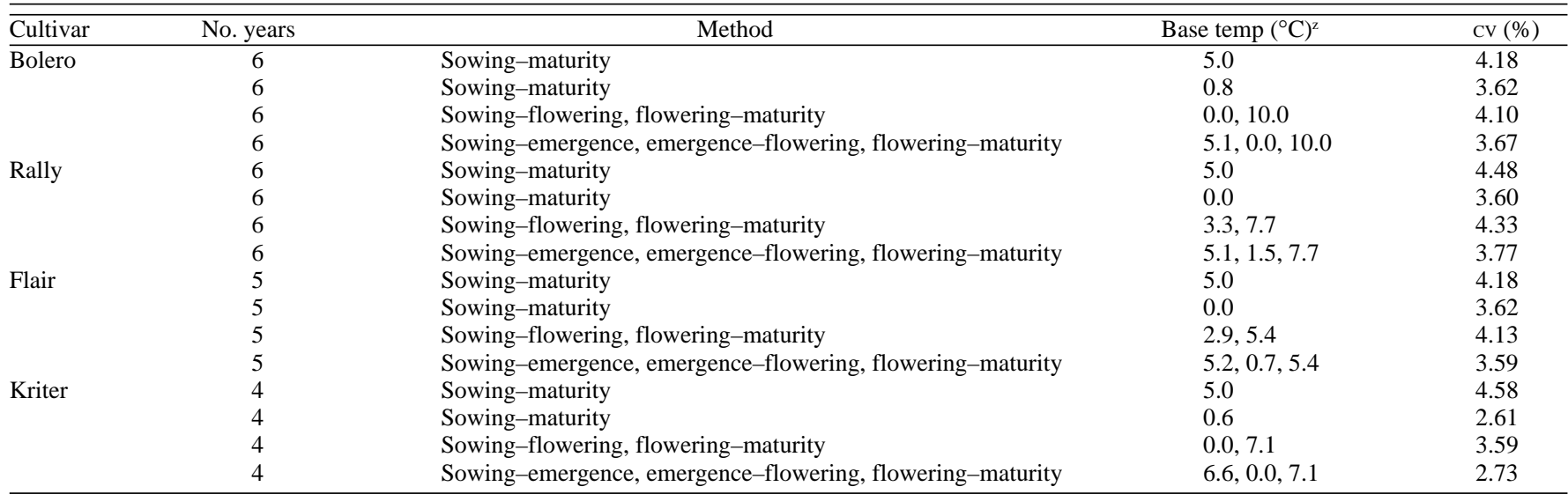

${ }^{2}$ All base temperatures minimize $\mathrm{Cv}$ except for $5^{\circ} \mathrm{C}$, which is used commercially.

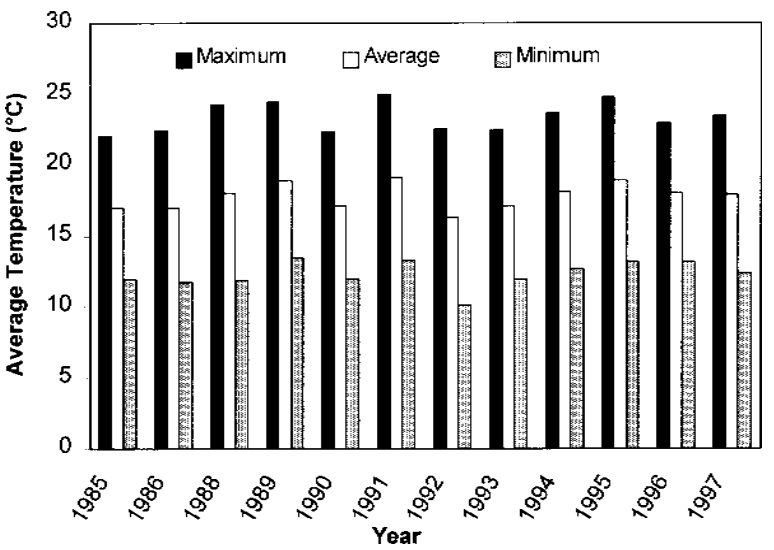

Fig. 1. Average temperatures observed during each growing period at the experimental farm of the Horticultural Research and Development Centre of Agriculture and Agri-Food Canada located at L'Acadie.

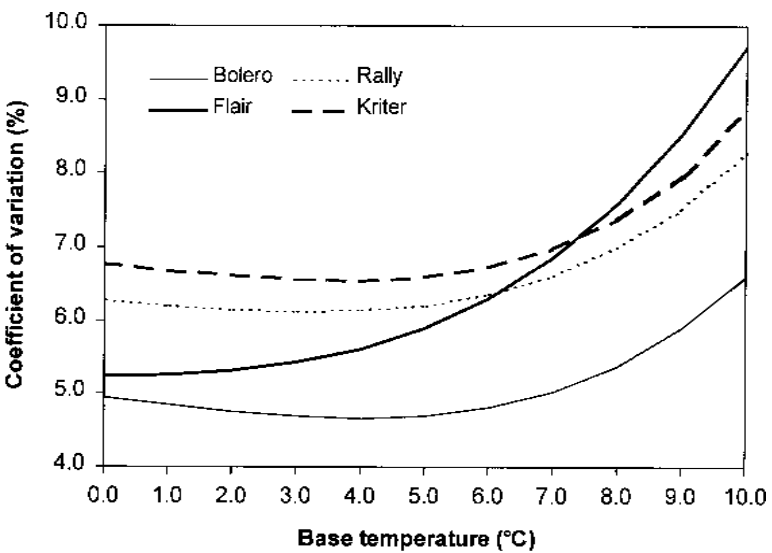

Fig. 2. Evolution of coefficient of variation with base temperatures used in a GDD formula estimating development time from sowing to maturity of four pea cultivars. 
maturity were calculated for each cultivar with base temperatures (Tbase) ranging from 0 to $10{ }^{\circ} \mathrm{C}$ in steps of $0.1^{\circ} \mathrm{C}$, using a spreadsheet software (MicrosoftExcel, Redmond, Wash.). The standard degree-day formula was: GDD = $($ Tmax + Tmin $) \times 0.5-$ Tbase, where GDD = 0 for GDD $<0$. All years with available emergence date from 1985 to 1997 were integrated in the calculation (Table 2). Statistical parameters were calculated from this database for the GDD obtained for each year and cultivar: mean, standard deviation, and coefficient of variation $(\mathrm{Cv})$. The base temperatures presenting the lowest $\mathrm{CV}$ for: 1) sowing to emergence, 2) sowing to flowering, 3 ) sowing to maturity, 4) emergence to flowering, 5) emergence to maturity, and 6) flowering to maturity were selected (Arnold, 1959). Coefficients of variance were also calculated for the combination of: 1) sowing to flowering and flowering to maturity, and 2) sowing to emergence, emergence to flowering, and flowering to maturity, using base temperatures that minimized $\mathrm{CV}$ for each period.

\section{Results and Discussion}

For the first part of the analysis, only years with all stages observed were used. For all cultivars, using a base temperature between 0.0 and $0.8^{\circ} \mathrm{C}$ to compute GDD reduced the CV in comparison with $5.0^{\circ} \mathrm{C}$ (Table 3 ), indicating that the base temperature used commercially is probably not the most appropriate for Quebec conditions ( $\mathrm{CV}=3.62 \%, 3.60 \%, 3.62 \%$, and $2.61 \%$ for 'Bolero', 'Rally', 'Flair', and 'Kriter', respectively). On the other hand, increasing the complexity of the simple, commercially used model by adding intermediate crop stages, did not substantially reduce the value of the $\mathrm{cv}$. This was especially the case with the second approach where emergence was not considered ( $\mathrm{CV}=4.10 \%, 4.33 \%, 4.13 \%$, and $3.59 \%$ for 'Bolero', 'Rally', 'Flair', and 'Kriter', respectively). The third approach gave CV's similar to those from the first approach adapted with a lower base temperature condition $(\mathrm{CV}=3.67 \%, 3.77 \%, 3.59 \%$, and $2.73 \%$ for 'Bolero', 'Rally', 'Flair', and 'Kriter', respectively). Using base temperatures specific for each crop phase did not improve the prediction of maturity in comparison with using an overall base temperature. Therefore, the simplest GDD model with a corrected base temperature was selected for the following steps of the analysis.

All available years for a given cultivar were then used to determine the base temperature with the lowest $\mathrm{CV}$ for predicting the time from sowing to maturity (Fig. 2). A base temperature from 0 to $5{ }^{\circ} \mathrm{C}$ was generally adequate for all cultivars. The base temperatures with the lowest $\mathrm{CV}$ for the cultivars Bolero, Rally, Flair, and Kriter were 4.0, 3.3, 0.0 , and $3.7^{\circ} \mathrm{C}$, respectively. The weighted average of $3.0^{\circ} \mathrm{C}$, which considers the number of observations for each cultivar, was selected as a common base temperature for all cultivars.

Four different models to predict harvest dates were then compared in terms of pre- diction date: 1) average number of days between sowing and maturity, 2) average number of GDD with a base temperature of $5{ }^{\circ} \mathrm{C}, 3$ ) average number of GDD with an optimal base temperature for each cultivar, and 4) average number of GDD with a base temperature of $3{ }^{\circ} \mathrm{C}$ (Table 4$)$. The difference between observed and predicted harvest dates The sum of squares of the differences indicated the overall precision of each model prediction for a given cultivar. The GDD approach improved the prediction of the harvest date over model 1 by integrating the effect of of these four models was calculated (Table 5).

Table 4. Description of selected models to predict harvest date. ${ }^{\mathrm{z}}$

\begin{tabular}{|c|c|c|c|c|c|c|c|}
\hline \multirow[b]{2}{*}{$\underline{\text { Cultivar }}$} & \multirow{2}{*}{$\begin{array}{c}\text { Model 1 } \\
\text { No. days from } \\
\text { sowing to harvest }\end{array}$} & \multicolumn{2}{|c|}{ Model 2} & \multicolumn{2}{|c|}{ Model 3} & \multicolumn{2}{|c|}{ Model 4} \\
\hline & & BT & $\begin{array}{l}\text { Mean } \\
\text { GDD }\end{array}$ & BT & $\begin{array}{l}\text { Mean } \\
\text { GDD }\end{array}$ & BT & $\begin{array}{l}\text { Mean } \\
\text { GDD }\end{array}$ \\
\hline Bolero & 63 & 5.0 & 800 & 4.0 & 863 & 3.0 & 926 \\
\hline Rally & 59 & 5.0 & 749 & 3.3 & 849 & 3.0 & 867 \\
\hline Flair & 57 & 5.0 & 713 & 0.0 & 996 & 3.0 & 826 \\
\hline Kriter & 57 & 5.0 & 711 & 3.7 & 784 & 3.0 & 824 \\
\hline
\end{tabular}

${ }^{\mathrm{z}}$ Model 2: base temperature (BT) of $5^{\circ} \mathrm{C}$; Model 3: optimal BT for each cultivar; Model 4: BT of $3{ }^{\circ} \mathrm{C}$.

Table 5. Observed and predicted time to maturity of pea cultivars using four selected models.

\begin{tabular}{|c|c|c|c|c|c|c|}
\hline \multirow[b]{3}{*}{ Year } & \multirow{2}{*}{\multicolumn{2}{|c|}{ Observed day of year at: }} & \multicolumn{4}{|c|}{ Difference between observations and predictions $(\mathrm{d})^{\mathrm{z}}$} \\
\hline & & & \multicolumn{4}{|c|}{ Maturity ${ }^{y}$} \\
\hline & Sowing & Maturity & Model 1 & Model 2 & Model 3 & Model 4 \\
\hline \multicolumn{7}{|c|}{ Bolero } \\
\hline 1986 & 133 & 202 & -6.0 & -3.8 & -4.0 & -4.2 \\
\hline 1989 & 138 & 196 & 5.0 & -2.1 & -1.7 & -1.4 \\
\hline 1990 & 129 & 200 & -8.0 & -3.8 & -4.1 & -4.4 \\
\hline 1991 & 133 & 191 & 5.0 & -0.5 & -0.3 & 0.0 \\
\hline 1992 & 140 & 204 & -1.0 & 4.0 & 3.6 & 3.2 \\
\hline 1993 & 132 & 196 & -1.0 & 2.6 & 2.7 & 2.0 \\
\hline 1994 & 141 & 199 & 5.0 & -0.9 & -0.7 & -0.5 \\
\hline 1995 & 130 & 189 & 4.0 & 0.9 & 1.0 & 1.1 \\
\hline 1996 & 130 & 198 & -5.0 & -2.7 & -2.8 & -3.0 \\
\hline 1997 & 142 & 199 & 6.0 & -0.6 & -0.3 & 0.0 \\
\hline \multicolumn{3}{|c|}{ Sum of squares of the differences } & 254.0 & 65.5 & 63.5 & 63.4 \\
\hline \multicolumn{7}{|c|}{ Rally } \\
\hline 1985 & 134 & 200 & -7.0 & -3.8 & -4.1 & -4.2 \\
\hline 1986 & 133 & 202 & -10.0 & -7.0 & -7.5 & -7.5 \\
\hline 1988 & 153 & 207 & 5.0 & -2.0 & -1.5 & -1.4 \\
\hline 1989 & 138 & 192 & 5.0 & -1.6 & -1.1 & -1.0 \\
\hline 1990 & 129 & 195 & -7.0 & -2.1 & -2.9 & -3.0 \\
\hline 1991 & 133 & 188 & 4.0 & -0.9 & -0.6 & -0.5 \\
\hline 1992 & 140 & 199 & 0.0 & 4.9 & 4.0 & 3.8 \\
\hline 1993 & 132 & 193 & -2.0 & 1.7 & 1.3 & 1.2 \\
\hline 1994 & 141 & 194 & 6.0 & 0.7 & 1.2 & 1.3 \\
\hline 1995 & 130 & 185 & 4.0 & 1.7 & 1.8 & 1.8 \\
\hline 1996 & 130 & 193 & -4.0 & -0.9 & -1.3 & -1.4 \\
\hline 1997 & 142 & 197 & 4.0 & -1.5 & -1.1 & -1.1 \\
\hline Sum & the differ & & 352.0 & 108.4 & 109.5 & 110.4 \\
\hline \multicolumn{7}{|c|}{ Flair } \\
\hline 1989 & 138 & 192 & -3.0 & -4.1 & -2.5 & -3.3 \\
\hline 1990 & 129 & 195 & -9.0 & -4.9 & -6.1 & -5.4 \\
\hline 1992 & 140 & 197 & 0.0 & 3.8 & 2.5 & 3.2 \\
\hline 1993 & 132 & 192 & -3.0 & 0.4 & -0.6 & -0.1 \\
\hline 1994 & 141 & 194 & 4.0 & -1.9 & -0.7 & -1.3 \\
\hline 1995 & 130 & 184 & 3.0 & 0.8 & 1.0 & 0.9 \\
\hline 1997 & 142 & 195 & 4.0 & -1.6 & -0.6 & -1.0 \\
\hline Sum & the differ & & 140.0 & 61.1 & 52.3 & 54.1 \\
\hline \multicolumn{7}{|c|}{ Kriter } \\
\hline 1985 & 134 & 196 & -5.0 & -1.9 & -2.2 & -2.4 \\
\hline 1986 & 133 & 199 & -9.0 & -7.3 & -7.6 & -7.7 \\
\hline 1988 & 153 & 206 & 4.0 & -3.3 & -2.8 & -2.6 \\
\hline 1989 & 138 & 189 & 6.0 & -1.2 & -0.7 & -0.5 \\
\hline 1990 & 129 & 194 & -8.0 & -4.0 & -4.4 & -4.6 \\
\hline 1991 & 133 & 185 & 5.0 & -0.4 & -0.1 & 0.1 \\
\hline 1992 & 140 & 197 & 0.0 & 3.6 & 3.2 & 3.0 \\
\hline 1993 & 132 & 191 & -2.0 & 1.3 & 1.0 & 0.8 \\
\hline 1994 & 141 & 192 & 6.0 & -0.0 & 0.4 & 0.6 \\
\hline 1995 & 130 & 182 & 5.0 & 2.6 & 2.7 & 2.7 \\
\hline \multicolumn{3}{|c|}{ Sum of squares of the differences } & 312.0 & 107.3 & 109.1 & 111.2 \\
\hline
\end{tabular}

zThe decimal value indicates the proportion of a day needed to reach the exact number of GDD.

${ }^{y}$ Based on average days between sowing and maturity (Model 1), average GDD with a base temperature (BT) of $5^{\circ} \mathrm{C}$ (Model 2), average GDD with an optimal BT for each cultivar (Model 3), and average GDD with a BT of $3{ }^{\circ} \mathrm{C}$ (Model 4). 
temperature in the model. However, the three models based on GDD gave very similar results for all cultivars.

For the years and cultivars used in this study, the computation of GDD with a base temperature of $3{ }^{\circ} \mathrm{C}$ (model 4$)$ gave an overall prediction of maturity of $2.0,2.4,2.2$, and $2.5 \mathrm{~d}$ based on the average of the absolute values of the differences for the cultivars Bolero, Rally, Flair, and Kriter, respectively (Table 5).

Alhough the study of $\mathrm{CV}$ indicated that $5^{\circ} \mathrm{C}$ was probably not the most appropriate base temperature for pea cultivars (Table 3 ), using another base temperature did not improve overall harvest prediction in terms of days (Table 5). However, cultivars appear to differ with regard to base temperature. 'Bolero', 'Rally', and 'Kriter' were quite insensitive to a change in base temperature within a range of 0 to $5^{\circ} \mathrm{C}$, whereas altering the base temperature from $0{ }^{\circ} \mathrm{C}$ tended to increase the $\mathrm{Cv}$ more rapidly for 'Flair' (Fig. 2).

Other parameters, such as soil temperature, soil water content, and sowing depth, need to be investigated to improve harvest prediction. Water stress can indeed affect pea development, the most sensitive moisture periods being just before flowering and during pod enlargement (Maurer etal., 1968; Rubatzky and Yamaguchi, 1997). Furthermore, the division of the growth period into distinct crop stages may eventually lead to a better predic- tion of harvest. With this approach, crop emergence and flowering need to be clearly defined in terms of crop phenology. For example, defining the flowering stage when $10 \%$ or $25 \%$ of the plants have at least one fully open flower may affect the precision of the model. Essentially, more precision is needed in the measurement of weather and biological parameters to achieve a better prediction of harvest.

\section{Literature Cited}

Arnold, C.Y. 1959. The determination and significance of the base temperature in a linear heat unit system. Proc. Amer. Soc. Hort. Sci. 74:430 445.

Borchers, E.A. 1981. The use of heat unit accumulation for the scheduling of vegetable plantings. Veg. Growers News. 36(1):2-4.

Boswell, V.R. 1927. The influence of temperature upon the growth and yield of garden peas. Proc. Amer. Soc. Hort. Sci. 23:162-168.

Boswell, V.R. 1929. Factors influencing yield and quality of peas, p. 341-382. In: Maryland Agr. Expt. Sta. Bul. 306.

Chaux, C. and C. Foury. 1994. Productions légumières. Tome 3. Légumineuses potagères, légumes fruits. Lavoisier, Paris Cedex 08.

Etévé, G. and M. Derieux. 1982. Variabilité de la durée de la phase végétative chez le pois (Pisum sativum L.). Application à la sélection de types résistants à l'hiver et à la détermination de la date de semis. Agron. 2:813-817.

Hoover, M.W. 1955. Some effects of temperature upon the growth of southern peas. Proc. Amer. Soc. Hort. Sci. 66:308-314.

Karr, E.J., A.J. Linck, and C.A. Swanson. 1959. The effect of short periods of high temperature during day and night periods on pea yields. Amer. J. Bot. 46:91-93.

Katz, Y.H. 1952. The relationship between heat unit accumulation and the planting and harvesting of canning peas. Agron. J. 44:74-78.

Lambert, R.G. and A.J. Linck. 1958. Effects of high temperature on yield of peas. Plant Physiol. $33: 347-350$

Lorenz, O.A. and D.N. Maynard. 1988. Knott's handbook for vegetable growers. $3^{\text {rd }} \mathrm{ed}$. Wiley, New York.

Maurer, A.R., D.P. Ormrod, and H.F. Fletcher. 1968 Response of peas to environment. IV. Effect of five soil water regimes on growth and development of peas. Can. J. Plant Sci. 48:129-137.

Ney, B., C. Duthion, and E. Fontaine. 1993. Timing of reproductive abortions in relation to cell division, water content, and growth of pea seeds. Crop Sci. 33:267-270.

Ney, B. and O. Turc. 1993. Heat-unit-based description of the reproductive development of pea. Crop Sci. 33:510-514.

Nonnecke, I.L., N.O. Adedipe, and D.P. Ormrod. 1971. Temperature and humidity effects on the growth and yield of pea cultivars. Can. J. Plant Sci. 51:479-484.

Rubatzky, V.E. and M. Yamaguchi. 1997. World vegetables: Principles, production, and nutritive values, $2^{\text {nd }}$ ed. Intl. Thomson Publ., Boston.

Swiader, J.M., G.W. Ware, and J.P. McCollum. 1992. Producing vegetable crops. Interstate Publ., Danville, Ill. 